\title{
TYPOLOGY OF METHODOLOGICAL APPROACHES TO CONSIDERATION OF THINKING
}

\section{Vozniak S. V.}

\section{INTRODUCTION}

The role of methodological issues is increasing in a situation oriented towards changing the current factors of the cultural and historical process. However, quite often, such requests turn to the search for tools, which would act automatically and could be externally attached to one or the other content as a universal method. But questions of methodology can be adequately considered only during their understanding as a particular specification of the human being in the space of thinking. The second half of the twentieth and early twenty-first centuries are characterized by attitudes toward the recognition of the worldview and intellectual paradigm of modern times, which requires radical thinking, and this inevitably pays attention to the analytics of existing approaches to understanding thinking, about the nature of which there is a considerable variety of ideas, sometimes simplistic and even false. It is not just about the stability of formal-logical prejudices. It is not just about the stability of formal-logical prejudices. Popular latest excursions into the nature of consciousness and thinking in the guise of "quantum theory", information theory, "synergistic methodolog" and others. The pursuit of "novelty" and "modernity", the focus on the "warping of time", "the achievement of modern science" - a clear symptom of bewilderment, which causes two equally false paths - the automatic pursuit of the latest trends or the same automatic confrontation with them. But the first necessary step is to think critically about the problem and to arrange a plurality of methods in fixing the essential basis of thinking.

Martin Heidegger points out that the question "What is called thinking?" cannot be answered by giving a conceptual definition of thinking, its definition and carefully expanding its content: "In what follows, we shall not think about what thinking is. We remain outside that mere reflection which makes thinking its object. Great thinkers, first Kant and then Hegel, have understood the fruitlessness of such reflection. That is why they had to attempt to reflect their way out of such reflection"1. Pays attention to the recognition of the futility of reflection on thinking. Did Kant and Hegel not reflect on thinking, did they not tell us how it works, how does thinking work?

${ }^{1}$ Heidegger M. What is called thinking? Ed. J. Glenn Gray. Harper Perennial, 1976. P. 21. 
Wasn't Kant's grand project of "criticism of the mind" a reflection on thinking, on our intellectual capacity to build scientific theories and create metaphysical systems? Apparently, Heidegger understands by "reflection" something specific, a certain kind of reflection - interprets it as a certain selfanalysis (up to introspection) of mental acts by the means of these acts, the thinking itself, and more precisely - by the means of the self-reporting that thinking about oneself that is, the logic that has evolved into "logistics", as he states: "In the West, thought about thinking has flourished as "logic". Logic has gathered special knowledge concerning a special kind of thinking. This knowledge concerning logic has been scientifically fruitful only quite recently, in a special science that calls itself "logistics". It is the most specialized of all specialized sciences. In many places, above all in the AngloSaxon countries, logistics is today considered the only possible form of strict philosophy, because its result and procedures yield an assured profit for the construction of the technological universe"2. Consequently, understanding thinking is connected with the task of comparing basic approaches to understanding the nature of thinking in modern humanitarian knowledge, outlining the methodological foundations of basic concepts of thinking in fundamental philosophical theories.

The current methodological situation in the humanitarian space can be described as pluralistic. This means that there is no single, guiding and "symptomatic of an era" approach to the problem of thinking. On equal terms, classical philosophical concepts of thinking, formed during the historicalphilosophical process - dating from antiquity, modern industry approaches to the understanding of thinking, and postmodern practices of interpreting thinking - can coexist in the same methodological field. Therefore, in the context of this discourse, it is necessary to consider all these points.

\section{The dominant modern methods in the research of thinking}

The starting point for thinking is the current intellectual situation, and it is appropriate to start analytics. Despite the fact that the variants of thinking strategies implemented in history are still valid today, the dominant factors are those ways of organizing cognition that depart somewhat from the classical ones. One of the first in non-classical philosophy was the formation of approaches to thinking based on positivism, psychologism, naturalism. In all the diversity of approaches to the research of thinking, it is possible to distinguish the methods and options for understanding the thinking, that are used by modern humanities, in particular psychology and pedagogy, newly formed methodological formations characteristic of our time, which seem to

\footnotetext{
${ }^{2}$ Heidegger M. What is called thinking? Ed. J. Glenn Gray. Harper Perennial, 1976. P. 21.
} 
be in the common intersection of the humanities, the sciences, and the natural sciences - for example, the information approach and the philosophical approaches to understanding thinking, which find their essential framework in fundamental philosophical concepts. Non-classical philosophy is characterized by a general distrust to the mind, which is no longer considered as the central most important part of the psyche and does not appear capable of the proper organization of human being. On this basis, this type of rationality is formulated, which is considered like not purely theoretical but life-practical - it determines the cultural-historical nature of the understanding of thinking when culture ceases to be an external "environment" of thought and becomes its internal form. We are moving to a multidimensional notion of thinking, accompanied by methodological attitudes of pluralism, subjectivism, relativism. Characteristic of these approaches is the reduction of thinking to a particular mental activity, based and determined by the neurophysiological activity of the human body. Research of the neurophysiological activity has considerable heuristic potential for solving problematic practical problems, but this type of research does not raise the issue of understanding the essential characteristics of thinking.

Orientation to the essential type of knowledge is a clear feature of philosophical strategies, so it is necessary to explicate the ways of thinking, inherent in philosophy, separating them from psychological-pedagogical approaches, which is not easy to do since in the history of human thought philosophical and psychological approaches are closely related. Psychology has a solid tradition of considering the nature of thinking, and it implements the ideas of the New European tradition of considering human beings within the framework of rational psychology in its concepts (as part of systematic philosophical knowledge), especially rooted in psychology is based on the empirical tradition. This tradition, in conjunction with the thinking of processing experienced data, recognizes the actions of thinking by distinguishing and identifying, analyzing and synthesizing, combining and generalizing. Relying on experience provides the opportunity to use experimental and scientific methods of research, which is characteristic of psychology. Modern psychological schools have undoubted achievements in the research of the phenomenal side of the thinking process when the task is to investigate thinking not in traces, signs and results, but in actual existence. It is important to note: firstly, in psychology, thinking is regarded as one of the psychic abilities of a person alongside others (perception, feeling, memory, etc.); secondly, thinking is recognized as connected with the cognitive sphere, but it is researched in close correlation with the body, and more precisely, with the nervous system and the brain of human, thirdly, thinking is investigated in the context of current and past experiences, the influence on 
the subject's attitudes, its emotions and values, so it applies to single empirical individual. When thinking is regarded as one of the mental faculties of humans, among others, it is an instance that regulates the forms of interaction between a living organism and the surrounding world, these interactions are mediated by some spontaneous activity of the organism. The psychological approach is also pedagogical, focusing on the features of thinking in connection with the individual-personal age characteristics of the person, so the emphasis is on awakening (more often talk about the formation and inoculation) of the act of thinking in a person - the ability to create justifiable judgments and to operate information. What is left out of the psychological and pedagogical approaches to thinking is the problematization of it, so it is taken as something in itself available and understood, the task is only to fix the various forms and ways of its emergence and action.

In the context of psychology "it is given a wide panorama of different concepts, which describes the forms, operations and schemes of decision, discusses models of the cycle of mentality. However, there is no coherent picture on the subject of thought, its framework is not maintained and thinking is often dissolved in a variety of irrational forms of activity"3. Accordingly, the information-cognitive strategy of thinking interpretation states that all acts of information processing are reduced to pattern recognition and problem solving. Cybernetic developments, along with the theory of information, took a broad direction, initially known as "artificial intelligence" and later as "cognitology" or "cognitive sciences". V.F. Yulov offers a technological approach that can claim a synthesis that is lacking in previous strategies, as it has incorporated a number of related ideas from different schools "and is alien to doctrinal unilateralism" ". On the basis of his strategy, the author defines thinking as the supreme information product - knowledge, which is structured in a sequence of acts, which ultimately gives a new intellectual product in the result. The author focuses his research on the sequence of intellectual acts otherwise it would not be a "technological strategy". According to V.F. Yulov, there are four acts of thinking: the act of problematization, the act of method mobilization, the instrumental act, the act of evaluating the result, which is in line with the spirit of modern technological and information society. It should be noted that in such a consideration there is no "tradition of philosophical reflection" - after all, the traditions of philosophical reflection include the consideration of categories as forms of thinking, the categorical nature of thinking. Thinking is often considered and analyzed from its

${ }^{3}$ Юлов В.Ф. Мышление в контексте сознания. М.: Академический Проект, 2005. C. 139 .

${ }^{4}$ Юлов В.Ф. Мышление в контексте сознания. М.: Академический Проект, 2005. C. 139 . 
operational side, so it describes an instrumental mind whose critique in the twentieth century emerged as one of the main tasks of philosophy (Max Gorkheimer, Theodor Adorno, Martin Heidegger).

The philosophical approach, in our view, is characterized by the understanding of thinking as such intellectual activity, which leads the person beyond the needs and forms of activity related solely to the body, being one of the determining factors (ways, forms) of human existence. Philosophy is not limited to the description of certain intellectual procedures (this is the prerogative of traditional logic), it is not limited to the ordering and processing of experimental data, but it rotates the gaze on the ways of giving the subject, becoming a "reflection of reflection", the second reflection. It views thinking as an attribute property of man in the context of the analytics of the specificity of the human way of being in general, human essence and materiality, analyzes thinking in the intense field of search for the ultimate foundations of the human being in the world. A purely philosophical understanding of thinking is offered by V.L. Petrushenko, emphasizing his ontological and anthropological character: thinking is such an intellectual activity, which deals first and foremost with the operation of the substantive content of consciousness, which causes thinking to lead a person to new encounters with being, to open and expand the horizons of being. "Through thinking, a person enters new realms of life, illuminates previously unknown regions of being, transforming them into components of the human universe. $<\ldots>$ Therefore, the question of thinking is a question of the substantive nature of human consciousness and vital activity. Productive thinking ability is the ability to respond not to the circumstances of life and environment, but to the existential meaning of it. Therefore, one cannot desire and begin to think creatively, productively, and one can only persistently cultivate an interest in encounters with being and a willingness to accept it in a way that it can open" ". The undoubted advantages of such an understanding are the adoption of a computational understanding of the nature of thinking "for the brackets", focusing on the semantic side and being on their own. Thinking has to do with the substantive content of consciousness, it gives effect to this content.

\section{Typology of methods in the historical and philosophical area}

Specifically philosophical approaches to the understanding of thinking can be classified on the basis of the historical development of philosophical thought. Classical philosophy in its historical movement actually forms not only individual approaches to the understanding of thinking, but creates a

5 Петрушенко В. Тлумачний словник основних філософських термінів. Львів: Видавництво Національного університету “Львівська політехніка”, 2009. С. 98-99. 
fundamental semantic framework in which thinking is generally problematized. To this end, it is worth mentioning the "methodological framework" proposed by V.S. Bibler, putting forward the idea of the existence in the European history of different intentions of the mind. He identifies four intentions of the mind, four independent forms of understanding. "The mind of antiquity (1) is focused on the actualization of 'eidos', the inner form of infinitely possible being. For the mind of Parmenides or Plato, Sophocles, or Phidias to understand means to define chaos, to lock it into space; it is an aesthesis understanding. Knowledge in the ancient sense is only one component of such an eidetic (one must find a holistic image of the world ...) understanding of things and one's own being. The medieval mind (2) is focused on updating the involvement of things and being to some universal subject, or, to speak of earthly things, to understanding objects as an extension of the definitions of the subject-Master. To understand means for such a mind to reveal the existence of things in their communion with the being, the purposes, the aspirations of the subject. Knowledge here again is one of the components of this dominant communion. Only the mind of the New Age (3) is all directed to the knowledge of things as they are in themselves, to the understanding of objects and of being solely as objects of knowledge. The usual identification of all forms of understanding with the knowing mind is, in my opinion, one of the sources of irrationalism $<\ldots>$ It is precisely in the dialogue of many minds in the modern orientation of the 'dialogical mind' (4) that the paradoxical and logically determined irreducibility of the irreducible one form of understanding, the ability to give a logical definition

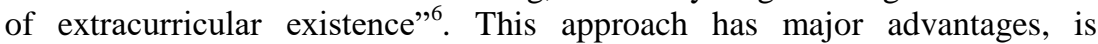
methodologically valuable, and can guide research opinion to previously unengaged options for interpreting its subject matter.

The first fundamental characteristics of thinking are formed within the framework of ancient philosophy - it is about constituting ontological features of thinking. A. F. Losev points out that, from the point of view of the ancient philosopher, all acts of recognition and identification, comparison and opposition are, for the first time, performed not by the human subject, but "by the same being, and the human subject only rotates that is created in being. Therefore, when it comes to unity, this unity firstly belongs to the same being, and only then does a person begin to think about it. $<\ldots>$ Such a being, which is itself opposed to itself and correlates with the rest, such self-relation is already a thinking of a number, not just a number. Such self-relation and

6 Библер В.С. Кант - Галилей - Кант (Разум Нового времени в парадоксах самообоснования). М.: Мысль, 1991. С. 14-15. 
correlation with everything else is what ancient thinkers called the mind"7. Therefore, in fact, the ancient mind is, first and foremost, the same objective reality that is given as such being, which itself correlates with itself and with every possible otherness.

In the doctrines of the representatives the School of Miletus we can see the intense movement of philosophical thought, although they do not have the doctrine about $\lambda$ oyo $\varsigma$ or vovs. However, a certain sense of thought as thought is already present. In relation to the first natural philosophical doctrines, V.L. Petrushenko notes that it begins as "thinking about everything", but: "from what should 'thinking about everything' begin? A thought that recognizes itself and realizes that it can encompass everything must start from some 'beginning'. <..> It is about the inner insights of consciousness itself, which means that it (consciousness) must not 'get lost' in variants of the idea about such beginning, so it must understand such beginning as a beginning for itself. This means that consciousness must find the basis for the internal acceptance of a particular judgment about the beginning. And this, in turn, means that the consciousness must be proving, argumentative, so it must proceed from some last for itself obviousness. The last obvious thing is what is it? It is such an intrinsic definition of a gaze that knows no obstacles, no internal breaks, no otherness, and which can be preserved when spreading the

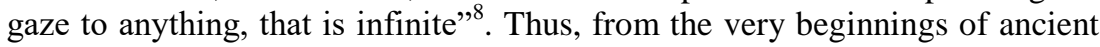
philosophy, the thought of their authors begins to operate differently than in everyday life, enters a different mode of their work, although it does not give a conscious report of it. "Everything is made of water", says Thales. Here, at the same time, is a demonstration of the characteristics of the beginning of the world, and the certainty of the idea that it has the "last evidentness".

The problem arises: how do the ancient notions of the existence of thought, the mind of being itself, and the movement of thought of the philosopher, his subjective thinking, relate to one another? In Thales, the movement of cognitive thought and the movement of world principle are, in fact, the same movement. Here at this point we are, in one way or another, entering into a complex and multifaceted, very ambiguous problem of the equality of thinking and being, which for the first time was quite clearly formulated by Parmenides.

In his Lectures on the History of Philosophy, Hegel believed that Parmenides began philosophy in its own sense since in his doctrine one must

\footnotetext{
${ }^{7}$ Лосев А.Ф. История античной эстетики. Итоги тысячелетнего развития: в 2 кн. Кн. $1 /$ А.Ф. Лосев. М. : Искусство, 1992. - С. 541-542.

8 Петрушенко В.Л. Парменид: концептуальный образ. Иов, или о человеческом самостоянии (исследования, эссе, размышления). Львов: Новый свит-2000, 2008. С. 118.
} 
see the ascension into the realm of the ideal. Precisely Parmenides is credited with introducing the concept of being into the philosophical circulation. And his statement: "To think and to be is the same things", or - "One and the same - thinking and what the thought" is the first in the history of philosophy to formulate the principle of the identity of thinking and being, a clear awareness of the indissoluble, essential connection of thought and being that is inherent in Greek philosophy. It is clear (after Parmenides) that the first and fundamental relation of thought is the relation to being: thought is the thought about being, the thought of being. After all, in everyday experience, we are emotionally confronted, speaking in the language of M. Heidegger, only with "being", but being as such is not given to us. However, according to Parmenides, it is given to us for thinking, for thoughts, for ideas.

To identify methodological approaches to thinking essential innovations sophists: firstly, thinking is detached from space and thus "given" in the hands of human, and thus opens the space for flexible and free existence of thought - to some extent this is the opening of the sphere of subjective, and secondly, sophists bet on cultivating the production of a special product - the product of the mental. Sophists are the figures who firstly discovered the internal patterns of the cognitive-reflexive process as an important component of history. Unlike the Sophists: "Socrates argued that true thought cannot be the property of man, since it can move only in the dimensions of meaning, and meaning implies absolute and ideation: true thought belongs to the motor of the determinants of being, not to the partial human interest" ${ }^{\text {"10 }}$.

This type of understanding of thinking is imitated by Plato: thinking (thinking consideration of things) is interpreted as the ability to see the universal order of things with which any single fact, act, phenomenon or guesswork should relate. In Plato's personality, human thinking reflects, appeals to itself, focusing on the system of those universal norms that govern the process of thinking cognition as the law. The subject of thinking here is the thinking, the categories in which it performs the processing of sensual images. Initially, this turnaround could not take place in any form other than objective idealism, so in the form of the idea, the system of universal forms of human activity is a self-contained, organized reality that resists all sensual, moreover, this reality is perfect, devoid of sensuality. Plato sharply contrasts the thinking with all the other faculties of the human soul. Thinking is about being, not becoming. The soul "in itself" views "as being in itself", and this

\footnotetext{
${ }^{9}$ Фрагменты ранних греческих философов. Часть 1. От эпических теокосмогоний до возникновения атомистики. М.: Наука, 1989. С. 287, 291.

10 Петрушенко В.Л. Парменид: концептуальный образ. Иов, или о человеческом самостоянии (исследования, эссе, размышления). Львов: Новый свит-2000, 2008. С. 169, 185.
} 
thinking contemplation differs sharply from all forms of the application of knowledge as a principle to the real knowledge of everything connected with sensuality.

Aristotle has a decisive role in developing the conceptual understanding of thinking. It is commonly called and valued as the creator of logic as the science of thinking. This is a certain prejudice. The principle of conformity of speech to things is the basic principle of the Aristotelian doctrine of syllogisms. If we talk about the true composition of the Aristotelian doctrine of thinking (its logic in the true sense of the word), its logic does not boil down to the doctrine of the connection of terms and expressions in syllogistic figures. The most significant in the Aristotelian interpretation of thinking is an appeal to the categories as to certain forms of mind work, and which Stagirith explains as kinds of utterances about being that correspond to the general kinds of being. Aristotle also has a purely ontological doctrine of the mind, of the super-cosmic mind. He calls it the place of all ideas, the deity, the form of all forms. It is worth mentioning that Martin Heidegger's emergence as a thinker occurred in the comprehension of Aristotle's legacy, but he does this in a slightly different way from Hegel - focusing on the "first entities"; he reads Aristotle phenomenologically.

Much attention to the understanding of thinking in antiquity is caused by the fact that there are given the first forms of intellectual work, which subsequently undergo various modifications. Thus, in accepting the ontological intensification of thought, the Middle Ages intensively and persistently mastered what we call spiritual reality: philosophical thought, when considering theological issues, "experiments" with infinite, invisible and sensually undetermined entities. In the traditions of scholasticism intensively researched, the apparatus of formal thinking is developed; in scholasticism, thinking persists in logical skill. It should also be noted that one of the fundamental phenomenological concepts - "intentionality" - is rooted precisely in the scholastic tradition of philosophizing.

The New European philosophical tradition subjectivizes the mind, considering thinking as a purely human capacity. This is especially true in the concepts of empiricism and sensuality and in the French enlightenment. The Cartesian concept of thinking deserves special attention. The principle of "Cogito ergo sum" pays tribute to the fact of thought that can attest to its very existence. The principle of "cogito", the content of "cogital" consciousness has been interestingly interpreted by M.K. Mamardashvili: "There is a law of thinking about philosophical texts - it can be expressed in this way: we are able to perceive what is written in philosophical text only if we are able to reproduce what is said in it (not words, but said in it) as an opportunity of ours of our own thinking - in the sense that we can think it too ... So the law is that 
if someone has ever performed an act of philosophical thinking, then it has everything that goes into philosophical thinking. In this sense, philosophy has nothing new, no inventions, because we can either think or not think, but if we think, we think what is already thought" ". In our view, Heidegger would agree with this argument: the intentions of his philosophy are directed not at introducing his own philosophy, but at clarifying, explicating, interpreting the thinking of being.

\section{Action-related type of understanding of thinking}

There is a tradition of considering thinking as a purely discursive logicalsequential process (the process by rules), but this is just one of the ways of understanding it. Another variant of philosophical understanding of thinking is based on the Spinoza-Hegelian-Marxist tradition: "Thinking as specifically human ability lies in the ability of a social person to perform his activity in harmony with the objective forms and laws of existence and development of objective reality, all whatever specific material it does not carry out, including activities in the field of language, in the material of signs, terms, words" ${ }^{\prime 2}$. Such considerations belong to philosophical classics and are therefore worthy of attention. The author assumes that the specificity of human being is the creative transformation of objective (both natural and social) reality in accordance with human goals. In order for such transformation not to be a distortion, not merely a consumption and use, but a creative extension of nature to culture, the human transformative activity must occur in accordance with the objective laws of self-motion of the transformed reality itself, conform to these laws, be specific - subjective - the continuation of the objective self-motion of a natural substance. Thinking as such is responsible for such coordination, compliance. It is on this side, in our view, that it can be adequately understood that being as such opens to human precisely in thinking.

Acting according to the essence of the matter (speaking in Hegelian language) is what should provide thinking as a human capacity. Therefore, from the point of view of E. V. Ilyenkov, the specificity of thinking lies in the absence of any "specificity", that is - in the universality. Because of this universality, human has access to being as such, not just to certain forms of being. In order to act according to the essence of the case, a person must constantly transform, rebuild, change the forms and schemes of his activity, so that this activity itself corresponds to the regularities of real processes. Such a change is ideally suited when the change is not about real things, events, but

${ }^{11}$ Мамардашвили М.К. Картезианские размышления. М.: Прогресс, Культура, 1993. C. $79-80$.

12 Ильенков Э. В. Гегель и проблема предмета логики. Философия Гегеля $u$ современность. М.: Мысль, 1973. С. 144. 
images of those things and events. This is where the place of the constructive, projective, instrumental side of thinking activity. But thinking as such does not come down completely and without rest to this side. Thinking must keep under control the whole process as the process of realizing human being both the purpose and the nature of the means and the realm of senses. In the opposite (purely instrumental) case, thinking appears only as a servant, an instrument, a means of achieving very limited, particular, selfish goals.

This type of approach to the understanding of thinking is unfolded in the burdens of German classical philosophy. Kant reveals the phenomenon of activity (spontaneity) of thinking. Firstly since Aristotle, he pays attention to the special role of categories (pure reasoning concepts) as a form of thought organization. To think is to cast a category grid on the experience data. According to Kant, the categories are a priori, so they are not a simple generalization of empirical things and are not innate in the biological sense. They organize our experience and thinking. Because of their a priori, categories are not things-to-themselves. Actually, Kant characterizes the mind as such by its ability to make judgments: it is the ability to apply rules, it cannot be set as a regular rule, or even as an arbitrarily extensive system of them. A smart person (a person endowed with judgment) at every step does just that - correctly applies any partial "rule". Kant says, "The lack of the power of judgment is that which is properly called stupidity, and such a failing is not to be helped" ${ }^{\prime 13}$. By creating transcendental logic, Kant breaks the narrow horizon of formal ("general") logic, giving it theoretical and cognitive status. Hegel's philosophy contains the most powerful concept of thinking in all classical philosophy, which creatively incorporates both the ideas of ancient thinkers and the immediate predecessors. The fact is that Hegel succeeded in making a real revolution in logic, the value of which is no less than the famous "Copernican revolution" of Kant. Hegel has criticized the centuries-old prejudice of formal logic that thinking is expressed only in speech. And is it not in human activity, in the creation of a grand body of culture and civilization, in the forms of movement of the human spirit - in art, religion, philosophy, science - that the power and power of human thinking are thus embodied? Hegel believes that traditional logic is hopelessly behind its "object": real thinking, which is expressed in the aggregate activity of mankind. Therefore, his task is to bring the science of thinking - logic - in line with its subject so clear and thus creates a "science of logic". In logic, Hegel integrates metaphysics with all its categories, thereby giving it logical status and logic ontology.

${ }^{13}$ Kant I. Critique of pure reason. Translated and edited by Paul Guyer, Allen W. Wood. Cambridge University Press, 1998. P. 268. 
Hegel's logic is dialectic (the combination of opposites, etc.), and dialectic is logic. Therefore, his logic is not a doctrine of external forms of thinking, but of the laws of motion and development of the objective and subjective world. The principle of the identity of thinking and being Hegel consciously, principally and consistently. "That the form of thinking is the absolute form and that the truth appears in it as it is in and for itself, this is the claim of philosophy in general" ${ }^{\prime 14}$. Philosophy is nothing more than a study of truth, but a study that recognizes the nature and value of the relationships of thought that bind and define any meaning. Hegel's thinking implicitly links to concepts but understands them fundamentally different than in conventional logic. It is necessary, he believes, "to take on the development of the concept and to submit one's thinking as well as one's mind to its logical necessity"15. If a human is different from animal thinking, then all humanity, Hegel believes, is only because it is produced by thinking - that thinking that is active in all humanity and gives all humanity its humanity. Often, Hegel is reproached for reducing a human to thinking, rationalizing the human being, subjugating everything to logic - in other words, Hegel improperly absolutizes thinking. But if you study the words of the thinker above, you can come to other conclusions. When Hegel argues that all humanity is made by thinking, only thinking imparts to humanity his humanity, in our view, he has a completely different understanding of thinking than his critics. If thought is interpreted as a particular kind of mental activity, then Hegel is clearly exaggerated and distorted here. But if one thinks in a Hegelian way, everything looks different. "Only thinking makes the soul (with which animals are also endowed) a spirit, and philosophy is only a consciousness of that content, the spirit and its truth"16.

Activity-based approach to the research of thinking is very common and important: this approach is characterized by such an understanding of thinking, when it is seen embodied in human activity and is the human ability to perform this activity not as desired, but clever, in accordance with the substance of the matter, but only for a moment because the conformity of the essence of the case involves the verification by the thinking of the level of

${ }^{14}$ Hegel Georg Wilhelm Friedrich. Encyclopedia of the Philosophical Sciences in Basic Outline, Part 1, Science of Logic. Translated and edited by Klaus Brinkman, Daniel O. Dahlstrom. Cambridge University Press, 2010. P. 63.

${ }^{15}$ Hegel Georg Wilhelm Friedrich. Encyclopedia of the Philosophical Sciences in Basic Outline, Part 1, Science of Logic. Translated and edited by Klaus Brinkman, Daniel O. Dahlstrom. Cambridge University Press, 2010. P. 20.

${ }^{16}$ Hegel Georg Wilhelm Friedrich. Encyclopedia of the Philosophical Sciences in Basic Outline, Part 1, Science of Logic. Translated and edited by Klaus Brinkman, Daniel O. Dahlstrom. Cambridge University Press, 2010. P. 16. 
dignity of the case, the level of correlation of this case with reality, and - most importantly - with the existence of other subjects (which is already moral and axiological and existential moments).

If we take the human way of being not simply in its object-transforming intention, but in the communicative area, then, in our opinion, there is the most adequate place and role of thinking in human life is highlighted. Human being as a community-social, communicative - is the emotional field of appeal to each other (and thus - to themselves). The conversion and reversibility of the relationship creates: the commitment to the being of others becomes a kind of causa sui of human being and all the forces of the human soul. In fact, "the relationship that engenders and reproduces man is that which arose naturally in the beginning of anthropogenesis, which is reproduced by the ontogeny of each of us throughout the millions of years of human history. It is the subjectively motivated attitude of each Homo sapiens individual to the subjectivity of other people and their relation to its subjectivity" ". In other words, the human community is generated and thus reproduced by the subjective motivation of counter-acts of co-feeling, co-action and co-thinking in every possible member. This guarantees the necessary productivity of their joint activities, which ensures joint survival. The projective and constructive moment of thinking is inscribed in the process of "transformation of affective meanings, which is practised to provide understanding to others of own treatment, in search of coaction, co-feeling, co-thinking with them (by the way, and with oneself). This is what the human essence of the matter really is, in aligning itself with which the thought process takes place.

On the basis of communicatively oriented methods, thinking is understood as the ability of each individual Homo sapiens to subjectively motivated expedient and arbitrary transformation of the cultural (universal) meaning of any object, and thus - to the generation of new meanings and senses"18. And further, the author argues that thinking arises and realizes itself in all cases of the appeal of each individual to other people and to himself. As a psychic phenomenon, thinking from the outset aims to gain affirmative consent with other people, while ensuring the unity and integrity of all abilities and processes of the human psyche. In all variants of its implementation, thinking remains a search, creative transformation of its own ways and means, and thus itself as a process. Outside of intense attention to the content and form of the meaning of each appeal to others and to oneself, thinking simply does not exist. Because one cannot think without following - and very meticulously -

${ }^{17}$ Михайлов Ф.Т. Самоопределение культуры. Философский поиск. М.: Индрик, 2003. C. 173.

18 Михайлов Ф.Т. Мышление. Теоретическая культурология. М.: Академический Проект; Екатеринбург: Деловая книга; РИК, 2005. С. 388. 
the process of expediently transforming the universal meanings of one's appeal to others and to oneself. To read aloud or not the text without following personal opinion, in its relation to its meaning, means not to think all the time; then you are a machine that simply sounds the text. To think is to convey, by own efforts, to another (and to oneself) a special, namely, personally necessary, sense of the object of appeal, while remaining true to universal semantic canons. The above understanding of thinking (even beforetheoretical, daily routine), in our opinion, is productive, because it fits intellectual activity into the real context of human activity, focusing on its attribution, creativity and indispensable dialogue. Then the calculated, projective, instrumental moments of thinking find their necessary place but do not cover all the content and scope of thinking activity.

If the activity-communicative concepts of thinking (which are also to some extent non-classical because they emphasize the practical-volitional aspect) tend to take the classical approach to thinking, they are widespread and extremely different methods, the general attitude about that is expressed by $\mathrm{R}$. Rorty in the second period of creation, he stands for the cultural-relativistic principles, contrary to the scientist tendencies of analytic philosophy and metaphysics. He does not accept the New European understanding of philosophy as such, which provides accurate representation of being (the "mirror") and asserts the rejection of any justification: "I present Wittgenstein, Heidegger, and Dewey as philosophers whose aim is to edify-to help their readers, or society as a whole, break free from outworn vocabularies and attitudes, rather than provide "grounding" for intuitions and customs of the present" 19 .

This turns thinking into a verbal game-talk by metaphors (redescription), which blocks the thinking beyond the visual.

\section{CONCLUSIONS}

Based on the analysis of the main approaches to the consideration of thinking, the importance of the philosophical approach is indicated, one of the central characteristics of it is the reversal the ray of view on the modes of givenness the subject, becoming a "reflection of reflection", a reflection of the second degree, which in the case of such an object as thinking, avoids its reduction to something already existing, pre-defined, grasped constructed definition that impedes the exploration of its essence. The philosophical and substantive approach is not measured to the description of certain intellectual procedures, is not limited to the ordering and processing of experimental data,

\footnotetext{
${ }^{19}$ Rorty R. Philosophy and the mirror of nature. Princeton, New Jersey: Princeton University Press, 1980. P. 11-12.
} 
does not stop at fixing the constructive, projective, instrumental side of thinking. Thinking as such does not completely come down to this side.

According to this approach it is emphasized that thinking holds under control the whole process of realization of human being - both the purpose, the nature of the means, and the realm of senses (the last - in the first place). The philosophical and essential approach considers thinking as an attribute property of human in the context of the analytics the specificity of the human way of being in general, human essence and materiality, analyzes thinking in the intense field of search for the limiting foundations of human being in the world.

The explication of the place and essence of thinking in the fundamental doctrines of classical philosophy testifies to the existence of deep ontological orientations in the interpretation of thinking, when thinking is taken and understood not simply as a human subjective capacity, along with other mental forces, but as something subjective in humanity corresponds to the deep existential dimensions, as evidence of human being's involvement.

Non-classical philosophy based on distrust of reason and the principles of methodological liberalism (pluralism) and cultures-relativistic historicism eliminates the essential approach to thinking, which leads to two extreme positions - the identification of thinking with formalized calculation and dissolution of thinking in a metaphorical arbitrary play of images.

\section{SUMMARY}

This article proposes a typology of methodological approaches to the consideration of thinking in philosophy. The division into a historicalphilosophical and action-related approach is offered. This separation is considered constructive by the author, since it gives an opportunity to generalize methodological approaches in the plane of theoretical and practical dimensions. The philosophical and substantive approach is not measured to the description of certain intellectual procedures, is not limited to the ordering and processing of experimental data, does not stop at fixing the constructive, projective, instrumental side of thinking. Thinking as such does not completely come down to this side. Non-classical philosophy based on distrust of reason and the principles of methodological liberalism (pluralism) and cultures-relativistic historicism eliminates the essential approach to thinking, which leads to two extreme positions - the identification of thinking with formalized calculation and dissolution of thinking in a metaphorical arbitrary play of images.

\section{REFERENCES}

1. Библер В.С. Кант - Галилей - Кант (Разум Нового времени в парадоксах самообоснования). М.: Мысль, 1991. 320 с. 
2. Ильенков Э.В. Гегель и проблема предмета логики. Философия Гегеля и современность. М.: Мысль, 1973. С. 111-120.

3. Лосев А.Ф. История античной эстетики. Итоги тысячелетнего развития: в 2 кн. Кн. 1. М.: Искусство, 1992. 656 с.

4. Мамардашвили М.К. Картезианские размышления. М.: Прогресс, Культура, 1993. 352 с.

5. Михайлов Ф.Т. Мышление. Теоретическая культурология. М.: Академический Проект; Екатеринбург: Деловая книга; РИК, 2005. С. 388-395.

6. Михайлов Ф.Т. Самоопределение культуры. Философский поиск. М.: Индрик, 2003. 272 с.

7. Петрушенко В.Л. Парменид: концептуальный образ. Иов, или о человеческом самостоянии (исследования, эссе, размышления). Львов: Новый свит-2000, 2008. С. 163-192.

8. Петрушенко В. Тлумачний словник основних філософських термінів. Львів: Видавництво Національного університету “Львівська політехніка", 2009. 264 с.

9. Фрагменты ранних греческих философов. Часть 1. От эпических теокосмогоний до возникновения атомистики. М.: Наука, 1989. 576 с.

10. Юлов В.Ф. Мышление в контексте сознания. М.: Академический Проект, 2005. 493 с.

11. Hegel, G. Encyclopedia of the Philosophical Sciences in Basic Outline, Part 1, Science of Logic. Translated and edited by Klaus Brinkman, Daniel O. Dahlstrom. Cambridge University Press, 2010. 380 p.

12. Heidegger, M. What is called thinking? Ed. J. Glenn Gray. Harper Perennial, 1976. 272 p.

13. Kant, I. Critique of pure reason. Translated and edited by Paul Guyer, Allen W. Wood. Cambridge University Press, 1998. 785 p.

14. Rorty, R. Philosophy and the mirror of nature. Princeton, New Jersey: Princeton University Press, 1980. 402 p.

\section{Information about the author:} Vozniak S. V.,

Candidate of Sciences (Philosophy), Associate Professor at the Department of Philosophy, Sociology and Religious Studies, Faculty of Philosophy, Vasyl Stefanyk Precarpathian National University 57, V.Chornovola str., Ivano-Frankivsk, 76015, Ukraine 